\title{
KAJIAN INOVASI DAN PENDAPATAN UNIT PENGOLAHAN IKAN DI LHOK SEUDU DESA LAYEUN KECAMATAN LEUPUNG KABUPATEN ACEH BESAR
}

(A Study Of Innovation and Income in Fish Processing Business Unit

in Lhok Seudu Layeun Village of Leupung Sub-District of Great Aceh Regency)

\author{
Laina Mawaddah ${ }^{1}$, T. Makmur ${ }^{1}$, Indra ${ }^{1 *}$ \\ ${ }^{1}$ Program Studi Agribisnis, Fakultas Pertanian, Universitas Syiah Kuala
}

\begin{abstract}
Abstrak - Pengolahan ikan merupakan salah satu bagian penting dari mata rantai industri perikanan. Pengolahan ikan bertujuan untuk memanfaatkan ikan yang tidak laku dijual dalam bentuk ikan segar atau ikan yang kurang digemari masyarakat. Lhok Seudu merupakan salah satu daerah yang mayoritas masyarakatnya melakukan proses pengolahan ikan. Adapun tujuan dari penelitian ini adalah untuk mengetahui tahapan proses pengolahan ikan, besarnya biaya dan pendapatan yang diperolah serta inovasi yang dapat diterapkan untuk meningkatkan pendapatan para pengolah ikan di Lhok Seudu Desa Layeun Kecamatan Leupung Kabupaten Aceh Besar. Penelitian ini dilakukan dengan metode sensus. Metode analisis yang digunakan adalah metode deskriptif kuantitatif yang diuji dengan menggunakan analisis pendapatan. Hasil penelitian menunjukkan bahwa : (1) Tahapan proses pengolahan ikan yang ada di Lhok Seudu masih dilakukan secara sederhana; (2) Pendapatan yang diperoleh para pengolah ikan adalah sebesar Rp. 4.235.090/bulan dengan R/C rasio yang diperoleh adalah sebesar 1,3; (3) Inovasi yang dapat diterapkan adalah pengadaan tempat pendingin atau freezer, pengadaan para-para jaring marlin dan pengadaan kemasan atau packaging.
\end{abstract}

Kata Kunci : Pengolahan Ikan, Inovasi, Pendapatan

\begin{abstract}
Fish processing business is one of the most significant parts in fishery industry. The fish processing aims to select the fish that are unsaleable or disliked by the costumers in the market. Lhok Seudu is one of regions where most of its inhabitants run fish processing business. This study aimed to explore the stages of fish processing, the cost, and, the revenue gained, as well as the applicable innovation to boost up the income received by local people in Lhok Seudu Layeun Villageof Leupung Sub-District in Great Aceh Regency, the ones who are involved in this business. The research method employed in this study was census. The data were analyzed by means of quantitative descriptive were tested using profitability analysis methods. The results showed that: (1) The stages of fish processing in Lhok Seudu were all done in a simple way; (2) The income received by local people who run this business was as much as IDR4.235.090/month with $\mathrm{R} / \mathrm{C}$ ratio of 1.3 ; (3) The applicable innovations included the procurement of freezer, nylon marlin net, and product packaging.
\end{abstract}

Keywords: Fish Processing, Innovation, Income

"Corresponding author: indra_ipb@yahoo.com

JIM Pertanian Unsyiah - AGB, Vol. 2, No. 2, Mei 2017: 250-263 


\section{PENDAHULUAN}

Indonesia merupakan negara kepulauan (Archipelagic country) yang memiliki sumberdaya perikanan dan kelautan yang melimpah. Lebih dari $70 \%$ wilayah Indonesia merupakan laut dengan keanekaragaman yang tinggi. Laut inilah yang menghubungkan lebih dari 17.000 daratan pulau-pulau besar dan kecil. Potensi lestari ikan laut nasional sekitar 6,4 juta ton per tahun (Mulyadi, 2005).

Komoditas perikanan mempunyai kecenderungan meningkat di pasaran dunia ditengah merosotnya perdagangan komoditas pertanian dan bahan pangan lainnya. Pemerintah terus berupaya untuk merangsang pertumbuhan industri perikanan agar dapat meningkatkan produksinya untuk ekspor, sekaligus akan bermanfaat untuk meningkatkan hasil devisa negara dan sebagai saluran pemasaran baru bagi produksi rakyat ke luar negeri. Dengan pengembangan perikanan akan mendorong para investor baik dalam negeri maupun luar negeri untuk menginvestasikan modalnya disektor perikanan (Khairul, 2003).

Aceh merupakan salah satu provinsi yang memiliki produksi ikan yang melimpah. Tingginya hasil produksi ikan di Aceh mendorong para masyarakat untuk melakukan inovasi terhadap hasil produksi ikan untuk menghindari kerusakan pada ikan dengan melakukan pengolahan. Perkembangan industri pengolahan ikan di Aceh tidak terlepas dari peran serta masyarakat dalam menjalankan kegiatan usaha pengolahan ikan sehinggga banyak masyarakat yang bekerja di sektor industri pengolahan ikan. Mereka tentunya tersebar dalam berbagai bidang industri seperti rumah tangga maupun usaha kecil lainnya.

Kegiatan pengolahan hasil perikanan merupakan aktivitas penting dalam kegiatan bisnis perikanan. Di samping untuk memanfaatkan ikan yang tidak laku dijual dalam bentuk ikan segar atau ikan yang kurang digemari masyarakat, dalam kegiatan pengolahan ikan perlu diterapkan inovasi dalam pengolahan ikan. Dengan adanya inovasi, memungkinkan adanya pengembangan produk baru yang lebih diminati masyarakat, sehingga dapat meningkatkan pendapatan produk olahan ikan tersebut.

Inovasi adalah suatu ide atau gagasan baru/unik dan berbeda yang belum pernah ada sebelumnya. Sifat ikan yang mudah rusak dan busuk dapat mengakibatkan kerugian bagi para nelayan sehingga mereka perlu melakukan pengolahan pada ikan tersebut. Inovasi dalam sektor perikanan merupakan hal yang penting untuk meningkatkan kualitas produksi dan meminimalisir segala kerusakan hasil laut guna untuk meningkatkan nilai tambah masyarakat.

Salah satu pusat pengolahan ikan yang ada di Aceh yaitu terdapat di Lhok Seudu Kecamatan Leupung Kabupaten Aceh Besar. Lhok Seudu terletak di desa Layeun yang merupakan sebuah desa pesisir yang memiliki garis pantai yang indah dengan kekayaan lautnya yang melimpah dan beranekaragam.Kegiatan proses pengolahan ikan yang ada di Lhok Seudu masih dilakukan secara sederhana dimana proses pengolahan ikan yang dilakukan secara manual dan belum menggunakan tekhnologi. Adapun proses pengolahan ikan yang ada di Lhok Seudu yaitu dengan cara penjemuran dibawah matahari. Ikan yang diolah dijemur pada tempat terbuka di pinggir jalan. Penjemuran di tempat yang terbuka 
pada dasarnya tidak baik karena dapat terkontaminasi oleh kuman yang membuat ikan cepat berjamur dan dapat menimbulkan penyakit.

Ikan yang sudah diolah biasanya juga dijual dalam keadaan terbuka dengan cara digantungkan pada tiang-tiang kios (sokes) yang ditempati masyarakat. Selain ikan yang digantung juga ada ikan yang ditumpuk-tumpuk diatas meja begitu saja tanpa ada perlakuan khusus. Pada dasarnya hal seperti ini sangat tidak layak karena dapat terkena langsung dengan debu.

Hal seperti ini umumnya terjadi karena kurangnya inovasi yang dapat dilakukan masyarakat. Ikan yang diolah bisa saja dikemas dengan kemasan yang lebih bagus agar dapat terhindar dari kotoran dan debu yang dapat menurunkan kualitas produk. Selain itu pengemasan juga berfungsi sebagai daya tarik bagi wisatawan yang ingin membeli oleh-oleh dari Lhok Seudu mengingat banyaknya wisatawan yang sengaja datang untuk membeli ikan olahan di Lhok Seudu.

Adapun tujuan dari penelitian ini adalah untuk mengetahui tahapan prosen pengolahan ikan, besarnya biaya yang dikeluarkan dan pendapatan yang diterima pengolah ikan dan inovasi yang diterapkan untuk meningkatkan pendapatan para pegolah ikan di Lhok Seudu Desa Layeun Kecamatan Leupung Kabupaten Aceh Besar.

\section{METODE PENELITIAN}

Metode yang digunakandalampenelitianiniadalahmetodesensus (sampling jenuh) dimana semua individu yang ada di dalam populasi dicacah sebagai responden.Jenis data yang dikumpulkandalampenelitianiniadalah data primer dan data sekunder.Data primer diperolehdariobservasi langsung menggunakan panduan wawancara yang telah dipersiapkan terlebih dahulu sesuai dengan tujuan penelitian.Data sekunder diperoleh dari instansi-instansi yang terkait dengan penelitian baik dari instasi pemerintah, swasta maupun perpustakaan.

Berdasarkan hipotesis yang telah diuraikan, maka metode analisis yang digunakan adalah metode deskriptif dengan menggunakan pendekatan kuantitatif yang menggambarkan fakta-fakta dan menjelaskan keadaan dari objek penelitian berdasarkan fakta yang ada serta menganalisa kebenaran berdasarkan data yang diperoleh dilapangan dan ditabulasi untuk dipindahkan ke dalam bentuk tabelaris yang sesuai dengan keperluan analisis pengujian.

Metode analisis dan pengujian hipotesis yang digunakan dalam penelitian ini, yaitu :

a. Biaya

Total biaya merupakan penjumlahan dari biaya tetap dan biaya variabel yang harus dikeluarkan. Secara sistematis dapat ditulis sebagai berikut :

$$
\mathrm{TC}=\mathrm{TFC}+\mathrm{TVC} \ldots \ldots \ldots \ldots \ldots(\text { Sukirno, } 2002)
$$

Dimana :

$\mathrm{TC}=$ Total biaya yang dikeluarkan (Rupiah)

$\mathrm{TFC}=$ Total biaya tetap yang dikeluarkan (Rupiah)

$\mathrm{TVC}=$ Total biaya variabel (Rupiah) 


\section{b. Penerimaan}

Total penerimaan merupakan nilai uang dari total produk atau hasil perkalian antara jumlah produksi $(\mathrm{Q})$ dan harga jual $(\mathrm{P})$. Secara matematis dapat ditulis sebagai berikut :

$$
\mathrm{TR}=\mathrm{Q} X \mathrm{P} \ldots \ldots \ldots(\text { Soekartawi, 1993) }
$$

Dimana :

$\mathrm{TR}=$ Total penerimaan (Rupiah)

$\mathrm{Q}=$ Jumlah produksi $(\mathrm{Kg})$

$\mathrm{P} \quad=$ Harga jual (Rupiah)

\section{c. Pendapatan}

Pendapatan merupakan pengurangan penerimaan total dengan biaya total. Secara matematis dapat ditulis sebagai berikut :

Dimana :

$$
\pi=\mathrm{TR}-\mathrm{TC} \ldots \ldots . . .(\text { Soekartawi, 1993) }
$$

$\pi=$ Pendapatan

$\mathrm{TR}=$ Total penerimaan

$\mathrm{TC}=$ Total biaya

\section{d. Revenue Cost Ratio $(R / C)$}

Revenue Cost Ratio (R/C) yaitu nilai yang didapat dari perbandingan antara penerimaan dengan total biaya yang dikeluarkan. Dengan rumus sebagai berikut :

Dimana :

$$
\mathrm{R} / \mathrm{C}=\frac{\mathrm{TR}}{\mathrm{TC}} \ldots \ldots \ldots . . .(\text { Soekartawi, 2006) }
$$

$\mathrm{TR}=$ Total penerimaan

$\mathrm{TC}=$ Total biaya

Dengan kriteria keputusan sebagai berikut :

$\mathrm{R} / \mathrm{C}<1$, maka usaha pengolahan ikan tidak layak untuk diusahakan

$\mathrm{R} / \mathrm{C}>1$, maka usaha pengolahan ikan layak untuk diusahakan

$\mathrm{R} / \mathrm{C}=1$, maka usaha pengolahan ikan dalam titik impas atau balik modal

\section{Tahapan Proses Pengolahan Ikan}

\section{HASIL DAN PEMBAHASAN}

Penanganan ikan segar merupakan salah satu bagian penting dari mata rantai industri perikanan dalam mengatasi kelebihan produk dari ikan segar. Penanganan ikan segar dilakukan dengan cara pengawetan melalui proses penggaraman. Adapun tujuan utama dari pengolahan ikan segar menjadi ikan asin untuk memperpanjang daya tahan, meningkatkan mutu, dan meningkatkan pendapatan para pengolah ikan.

Pengolahan ikan yang ada di Lhok seudu Desa Layeun Kecamatan Leupung Kabupaten Aceh Besar adalah ikan segar dari perairan laut yang dipeoleh dari tempat pelelangan ikan (TPI) Lokseudu dan diolah dengan cara penggaraman dan pengeringan (proses pengasinan). Adapun tahapan dalam usaha pengolahan ikan yaitu pengadaan bahan baku (input bahan baku), proses pengolahan ikan dan proses pemasaran hasil olahan ikan. 


\section{Pengadaan Bahan Baku (Input Bahan Baku)}

Bahan baku merupakan bahan dasar yang digunakan dalam proses pengolahan ikan. Bahan baku adalah segala sesuatu atau bahan-bahan dasar yang dipakai untuk memulai suatu produksi yang akan menghasilkan suatu produk yang baru. Bahan baku yang digunakan adalah berupa jenis ikan segar yang diperoleh dari tempat pelelangan ikan (TPI) Lhok Seudu. Biasanya para pengolah ikan membeli bahan baku satu kali dalam seminggu tergantung dengan ketersediaan ikan di tempat pelelangan ikan (TPI) Lhok Seudu.

Ketersediaan ikan di tempat pelelangan ikan (TPI) selalu ada, namun pada angin musim timur produksi ikan akan melimpah dan pada anginmusim barat produksi ikan akan mengalami panceklik. Hal ini dapat berdampak pada harga ikan. Jika ketersediaan ikan melimpah maka harga ikan akan murah dan sebaliknya jika mengalami panceklik maka harga ikan akan mahal. Namun hal ini tidak mempengaruhi para pengolah ikan untuk melakukan pengolahan ikan meskipun harus mengeluarkan biaya lebih untuk untuk membeli bahan baku.

Bahan baku yang digunakan selain ikan adalah garam. Garam berfungsi sebagai pengawet yang digunakan untuk menjaga ikan agar bisa tahan lebih lama. Selain itu pun garam juga berfungsi sebagai perasa pada ikan yang diolah. Biasanya para pengolah ikan menggunakan garam sebanyak 3-10 Kg dalam setiap kali produksi tergantung banyaknya ikan yang digunakan. Harga garam per $\mathrm{Kg}$ nya yaitu Rp. 5.000.

\section{Proses Pengolahan Ikan}

Pengolahan ikan adalah proses pembuatan ikan segar menjadi produk baru yang dapat meningkatkan nilai jual ikan tersebut. Proses pengolahan ikan yang yang ada di Lhok Seudu Desa Layeun Kecamatan Leupung Kabupaten Aceh Besar adalah ikan segar dari perairan laut yang diolah dengan cara penggaraman dan pengeringan. Adapun tahapan-tahapan proses pengolahan ikan adalah sebagai berikut :

\section{a. Penyediaan bahan baku dan peralatan}

Bahan baku berupa ikan segar dibeli dari tempat pelelangan ikan (TPI) Lhok Seudu yang jaraknya tidak jauh dari tempat-tempat pengolahan ikan. Di tempat pelelangan ikan (TPI) ikan- ikan tersebut sudah di sortir (dipilah dan dipilih) menurut mutu kesegaran, jenis dan ukuran ikan. Sehingga pengolah dapat langsung memilih ikan-ikan yang akan diolah baik dari segi mutu, ukuran ikan, dan jumlah ikan yang akan diolah. Adapun peralatan yang digunakan adalah pisau, ember, pembersih sisik ikan, sikat dan para-para.

\section{b. Penyiangan ikan}

Ikan yang telah dibeli kemudian dibawa ke tempat pengolahan untuk kemudian dilakukan penyiangan menggunakan alat pembersih sisik ikan agar ikan bersih dari kotorannya. Penyiangan ikan dilakukan dengan cara membersihkan ikan dari sisik dan insang.

\section{c. Pembelahan ikan}

Ikan yang telah disiangi kemudian dibelah dengan menggunakan pisau dan mengeluarkan isi perutnya. 


\section{d. Perendaman Ikan}

Ikan yang telah dibelah kemudian direndam di dalam fiber selama 1 malam agar kotoran dan darah yang menempel dapat mudah dibersihkan. Fiber adalah tempat untuk meletakkan ikan-ikan yang direndam.

\section{e. Pembersihan Ikan}

Setelah perendaman ikan, sisa-sisa kotoran dan darah yang menempel pada tubuh ikan dibersihkan dengan menyikat secara perlahan agar ikan dapat bersih dari sisa-sisa kotoran dan darah.

\section{f. Pencucian Ikan}

Ikan-ikan yang telah dibersihkan dari dari sisa-sisa kotoran dan darah kemudian dicuci dengan air bersih. Hal ini bertujuan untuk menghindari sisa-sisa kotoran dan darah yang melekat pada ikan.

\section{g. Pemberian garam dan perendaman}

Ikan-ikan yang telah dicuci kemudian diberikan garam. Garam yang digunakan dicampur dengan air bersih yang dimasukkan ke dalam ember besar. Kemudian ikan yang telah bersih dimasukkan ke dalam ember besar yang berisi garam tersebut dan direndam selama 1 malam. Tujuan perendaman ini agar larutan air garam tersebut meresap ke dalam ikan.

\section{h. Penjemuran ikan}

Setelah ikan direndam selama 1 malam dalam larutan garam di jemur di atas para-para untuk proses pengeringan. Para-para adalah wadah balok/papan yang diberi jaring kawat yang berfungsi sebagai tempat untuk menjemur ikan. Ikan akan diletakkan di atas para-para dan setelah cukup kering maka para-para tersebut akan diposisikan terbalik dari posisi semula dan kemudian para-para tersebut akan dipukul-pukul sehingga ikan-ikan kering yang lengket diatas parapara akan jatuh ke tempat penampungan.

Penjemuran dilakukan selama 1 hari. Namun proses penjemuran ini juga tergantung pada cuaca. Apabila pada saat proses penjemuran cuaca cerah maka penjemuran cukup dilakukan 1 hari, dan sebaliknya apabila cuacanya mendung penjemuran dilakukan dalam 2-3 hari. Ikan-ikan yang telah dijemur siap dijual kepada konsumen.

\section{Proses Pemasaran Hasil Olahan Ikan}

Pada daerah penelitian di Lhok Seudu Desa Layeun Kecamatan Leupung Kabupaten Aceh Besar, para pengolah ikan memasarkan sendiri hasil olahan ikannya di sokes yang terletak di pinggiran jalan raya. Sokes adalah kios-kios kecil yang ditempati para pengolah ikan untuk memasarkan hasil olahannya yang sekaligus di bagian belakang kios tersebut digunakan sebagai tempat untuk mengolah ikan.

Sokes yang ditempati para pengolah ikan adalah milik pribadi yang terletak di pinggiran jalan nasional Banda Aceh-Meulaboh. Biasanya para pengolah menjual ikan hasil olahannya dengan cara menumpukkan hasi-hasil olahan ikan di atas meja, bahkan ada sebagian ikan-ikan yang berukuran besar hanya digantunggantung di sisi tiang penyangga sokes mereka. Adapun konsumen yang membeli hasil olahan mereka adalah masyarakat yang berasal dari daerah sekitar yang melintasi jalan Banda Aceh-Meulaboh. Namun juga ada wisatawan lokal yang 
berbagai daerah lain dan wisatawan domestik yang berasal dari Malaysia yang biasanya datang untuk membeli hasil olahan mereka.

\section{Biaya Produksi}

Biaya produksi adalah biaya yang dikeluarkan oleh pengusaha selama proses produksi untuk menghasilkan suatu output produksi. Biaya produksi dapat dibedakan menjadi dua yaitu biaya tetap dan biaya variabel.Biaya tetap (fixed cost) merupakan biaya yang dikeluarkan dan tidak habis dipakai dalam satu kali masa produksi. Dalam penelitian ini biaya tetap yang digunakan adalah biaya penyusutan peralatan. Penyusutan merupakan berkurangnya nilai suatu barang yang disebabkan karena pemakaian, keusangan dan kemerosotan fisik (Kusnadi, 2000).Biaya tidak tetap (Variable cost) yaitu biaya yang dikeluarkan oleh pengusaha atau pengrajin sebagai akibat penggunaan faktor produksi variable sehingga biaya ini besarnya berubah-ubah sesuai dengan jumlah produk yang dihasilkan (Suparmoko, 2000). Dalam penelitian ini yang mencakup biaya tetap adalah biaya bahan baku dan biaya penunjang.Berikut adalah rata-rata biaya produksi pada unit pengolahan ikan di Lhok Seudu Desa Layeun Kecamatan Leupung Kabupaten Aceh Besar.

Tabel 1. Rata-rata Perincian Biaya Produksi pada Unit Pengolahan Ikan di Lhok SeuduDesa Layeun Kecamatan Leupung Kabupaten Aceh Besar, 2016

\begin{tabular}{|c|l|r|}
\hline No. & \multicolumn{1}{|c|}{ Uraian Biaya } & \multicolumn{1}{|c|}{ Rata-rata Biaya (Rp/Bulan) } \\
\hline 1. & Biaya Tetap & $69.428,57$ \\
& a. Biaya penyusutan peralatan & \\
\hline 2. & Biaya Tidak Tetap & 13.178 .750 \\
& a. Biaya bahan baku & 446.964 \\
\hline & b. Biaya penunjang & 13.704 .909 \\
\hline
\end{tabular}

Sumber: Data Primer (diolah), 2016

Berdasarkan tabel diatas dapat disimpulkan bahwa jumlah rata-rata seluruh biaya yang digunakan untuk biaya produksi adalah sebesar Rp. 13.704.909/bulan yang meliputi biaya tetap (fix cost) sebesar Rp. 69.428.57/bulan dan biaya tetap tetap (variable cost) sebesar Rp. 13.625.357/bulan. Biaya tetap pada proses pengolahan ikan di Lhok Seudu Desa Layeun Kecamatan Leupung Kabupaten Aceh Besar meliputi biaya penyusutan peralatan dan biaya tidak tetap meliputi biaya bahan baku dan biaya penunjang.

\section{Produksi, Harga Jual dan Nilai Produksi}

Produksi adalah hasil yang diperoleh dari proses pengolahan ikan dalam satu bulan dengan jumlah tertentu. Jumlah produksi antara satu pengolah dengan pengolah lainnya berbeda tergantung pada jumlah bahan baku yang digunakannya selama proses produksi berlangsung.

Harga jual adalah harga hasil olahan ikan yang dihitung tergantung pada jenis ikan yang digunakan, sedangkan nilai produksi adalah jumlah produksi dikalikan harga jual yang berupa penerimaan kotor yang dinyatakan dalam rupiah/bulan.Berikut adalah jumlah produksi dan nilai produksi pada unit pengolahan ikan di Lhok Seudu DesaLayeunKecamatan Leupung Kabupaten Aceh Besar. 
Tabel 2. Nilai Produksi pada Pengolahan Ikan di Lhok Seudu Desa Layeun Kecamatan Leupung Kabupaten Aceh Besar, 2016

\begin{tabular}{|c|l|r|r|r|}
\hline No. & \multicolumn{1}{|c|}{$\begin{array}{c}\text { Jenis Bahan } \\
\text { Baku }\end{array}$} & $\begin{array}{c}\text { Produksi } \\
(\mathrm{Kg})\end{array}$ & Harga Jual $(\mathrm{Rp} / \mathrm{Kg})$ & $\begin{array}{c}\text { Nilai Produksi } \\
(\mathrm{Rp} / \text { Bulan })\end{array}$ \\
\hline 1. & Tenggiri & 10.75 & 200.000 & 2.150 .000 \\
\hline 2. & Kuwe & 9.2 & 200.000 & 1.840 .000 \\
\hline 3. & Talang & 17.2 & 150.000 & 2.580 .000 \\
\hline 4. & Kakap & 3.75 & 200.000 & 1.750 .000 \\
\hline 5. & Salam & 4.75 & 120.000 & 408.000 \\
\hline 6. & Bawal & 10 & 150.000 & 712.500 \\
\hline 7. & Gurita & 32.5 & 40.000 & 2.400 .000 \\
\hline 8. & Kepala Batu & 38.5 & 50.000 & 1.300 .000 \\
\hline 9. & Udang Sabu & 37 & 80.000 & 1.925 .000 \\
\hline 10. & Teri & & 2.960 .000 \\
\hline \multicolumn{4}{|r|}{ Total Nilai Produksi } \\
\hline
\end{tabular}

Sumber : Data Primer (diolah), 2016

Berdasarkan tabel diatas dapat disimpulkan bahwa rata-rata nilai produksi pada unit pengolahan ikan di Lhok Seudu Desa Layeun Kecamatan Leupung Kabupaten Aceh Besar adalah sebesar Rp. 17.940.000/bulan dengan jumlah produksi yang berbeda-beda setiap jenis ikan yang diolah tergantung jumlah bahan baku yang digunakan. Selain jumlah bahan baku yang digunakan, jumlah produksi ikan juga dipengaruhi oleh permintaan konsumen.

\section{Pendapatan}

Pendapatan adalah penerimaan bersih atau laba yang diperoleh para pengolah ikan dalam proses produksi yang ditentukan oleh jumlah bahan baku yang digunakan dan harga jual hasil olahan ikan. Pendapatan yang diperoleh merupakan selisih antara penerimaan dengan biaya produksi yang dinyatakan dalam satuan rupiah. Berikut adalah rata-rata pendapatan yang diterima pada unit pengolahan ikan di Lhok Seudu Desa Layeun Kecamatan Leupung Kabupaten Aceh Besar.

Tabel 3. Rata-rata Pendapatan pada Unit Pengolahan Ikan di Lhok Seudu Desa Layeun Kecamatan Leupung Kabupaten Aceh Besar, 2016

\begin{tabular}{|c|c|r|}
\hline No. & Uraian & Jumlah (Rp/Bulan) \\
\hline 1. & Total Nilai Produksi (Rp/Bulan) & 17.940 .000 \\
\hline 2. & Total Biaya Produksi (Rp/Bulan) & 13.704 .909 \\
\hline \multicolumn{2}{|c|}{ Pendapatan } & 4.235 .090 \\
\hline
\end{tabular}

Sumber : Data Primer (diolah), 2016

Berdasarkan tabel diatas dapat disimpulkan bahwa rata-rata pendapatan para pengolah ikan di Lhok Seudu Desa Layeun Kecamatan Leupung Kabupaten Aceh Besar adalah sebesar Rp.4.235.090/bulan. Pendapatan ini diperoleh setelah total nilai produksi sebesar Rp17.940.000/bulan dikurangin dengan total biaya produksi sebesar Rp. 13.704.909/bulan. 


\section{Revenue Ratio Cost $(\mathbf{R} / \mathbf{C})$}

Analisis Revenue Cost Ratio $(R / C)$ merupakan nilai yang didapat dari perbandingan antara total penerimaan dan biaya yang dikeluarkan pada suatu usaha. Suatu usaha dikatakan layak apabila R/C lebih besar dari pada 1. Untuk mengetahui besarnya $\mathrm{R} / \mathrm{C}$ ratio yang diperoleh pada usaha unit pengolahan ikan dapat menggunakan rumus sebagai berikut :

$$
\begin{aligned}
& \mathrm{R} / \mathrm{C}=\frac{\text { Total Penerimaan }}{\text { Total Biaya Produksi }} \\
& \mathrm{R} / \mathrm{C}=\frac{17.940 .000}{13.704 .909} \\
& \mathrm{R} / \mathrm{C}=1,3
\end{aligned}
$$

Berdasarkan perhitungan di atas, nilai Revenue Cost Ratio pada usaha pengolahan ikan ini menunjukkan bahwa dari biaya produksi yang dikeluarkan sebesar Rp. 17.940.000maka akan diperoleh penerimaan sebesar 1,3. Artinya setiap penambahan biaya sebesar Rp. 1 akan menambah penerimaan sebesar 1,3. Nilai R/C lebih besar dari 1 sehingga dapat dikatakan bahwa unit pengolahan ikan yang ada di Lhok Seudu menguntungkan dan layak untuk diusahakan.

\section{Inovasi Yang Dapat Diterapkan Dan Dampak Terhadap Pendapatan}

Pada unit pengolahan ikan di Lhok Seudu semua proses pengolahan ikan dan proses pemasaran yang dilakukan masih sangat sederhana. Padahal di daerah ini mempunyai hasil produksi perikanan yang melimpah dan beragam. Selain itu konsumen yang membeli hasil olahan ikan tidak hanya berasal dari daerah sekitar namun juga berasal dari luar negeri. Untuk itu diperlukan inovasi yang dapat menunjang peningkatan produktivitas dan pendapatan para pengolah ikan dan untuk jangka panjang juga akan merubah prilaku dan meningkatkan kesejahteraan hidup masyarakat sekitar serta dapat mebangun kawasan perikanan yang baik. Adapun beberapa inovasi yang dapat diterapkan di daerah penelitian ini adalah :

\section{Inovasi Pengadaan Tempat Pendingin atau Freezer.}

Pada proses input, bahan baku yang tersedia akan melimpah pada angin musim timur dan bahan baku akan mengalami paceklik pada angin musim barat sehingga para pengolah ikan akan kekurangan bahan baku. Akibatnya pada saat bahan baku melimpah maka harga jualnya akan rendah dan sebaliknya pada musim paceklik harga jual bahan baku akan melambung tinggi sehingga para pengolah ikan harus mengeluarkan lebih banyak biaya untuk membeli bahan baku pada musim panceklik.

Anginmusim timur akan terjadi antara bulan april-oktober yaitu ketika letak semu matahari berada di belahan bumi utara sehingga menyebabkan tekanan udara wilayah Benua Asia menjadi rendah dan tekanan udara wilayah Benua Australia menjadi tinggi, hal tersebut akan menyebabkan angin bertiup dari Benua Australia ke Benua Asia. Karena angin tersebut harus melewati daerah gurun yang luas di Benua Australia sehingga udara sedikit mengandung uap air dan bersifat kering. Hal tersebutlah yang menyebabkan di Indonesia pada bulan april-oktober menjadi musim kemarau. sedangkan angin musim barat akan terjadi antara bulan oktober-april yaitu pada saat posisi semu matahari berada di belahan bumi selatan. Posisi inilah yang menyebabkan tetakan udara yang tinggi di Benua Asia dan tekanan udara yang rendah di wilayah Benua Australiayang membuat angin bertiup dari Benua Asia ke Benua Australia. Pada perjalanan dari Benua Asia ke 
Benua Australia angi melewati Samudra Hindia sehingga angin tersebut mengandung banyak uap air. Hal tersebutlah yang menyebabkan di Indonesia pada bulan oktober-april akan terjadi musim hujan.

Hal ini akan mengakibatkan pada angin musim timur produksi ikan akan melimpah karena angin musim timur bersifat kering dan akan menyebabkan kemarau sehingga memudahkan para nelayan untuk melaut. Sedangkan pada angin musim barat produksi ikan akan mengalami paceklik karena angin musim barat bersifat basah dan membawa hujan sehingga nelayan akan sulit untuk melaut. Apabila diberikan inovasi dapat dilakukan dengan penyimpanan bahan baku pada saat bahan baku sedang melimpah ke dalam tempat pendingin atau freezer dan dapat dikeluarkan kembali pada saat musim panceklik.

Untuk mengetahui pendapatan sebelum dilakukannya inovasi dengan pengadaan tempat pendingin atau freezer dapat diasumsikan sebagai berikut :

Tabel 4. Asumsi Perbandingan Pendapatan pada Angin Musim Timur dan Angin Musim Barat

\begin{tabular}{|c|l|c|r|}
\hline No. & \multicolumn{1}{|c|}{ Uraian } & $\begin{array}{c}\text { Angin Musim Timur } \\
\text { (Rp/Bulan) }\end{array}$ & $\begin{array}{c}\text { Angin Musim Barat } \\
\text { (Rp/Bulan) }\end{array}$ \\
\hline 1. & Nilai Produksi & 17.940 .000 & 17.940 .000 \\
\hline 2. & Biaya Produksi & 11.356 .159 & 14.159 .912 \\
\hline \multicolumn{2}{|c|}{$\begin{array}{c}\text { Jumlah Pendapatan } \\
\text { (Rp/Bulan) }\end{array}$} & 6.583 .841 & 3.780 .088 \\
\hline
\end{tabular}

Sumber : Data Primer (diolah), 2016

Dari tabel asumsi diatas dapat disimpulkan bahwa biaya produksi yang dikeluarkan pada angin musim barat lebih besar dibandingkan dengan biaya produksi yang dikeluarkan pada angin musim timur sehingga berpengaruh pada pendapatannya. Untuk mengetahui besarnya Revenue Ratio Cost pada inovasi yang diberikan ini maka dapat dihitung sebagai berikut :

$>$ Pada angin musim timur :

$$
\begin{aligned}
\mathrm{R} / \mathrm{C} & =\frac{\text { Total Penerimaan }}{\text { Total Biaya Produksi }} \\
\mathrm{R} / \mathrm{C} & =\frac{17.940 .000}{11.356 .159} \\
\mathrm{R} / \mathrm{C} & =1,5
\end{aligned}
$$

$>$ Pada angin musim barat :

$$
\begin{aligned}
\mathrm{R} / \mathrm{C} & =\frac{\text { Total Penerimaan }}{\text { Total Biaya Produksi }} \\
\mathrm{R} / \mathrm{C} & =\frac{17.940 .000}{14.159 .912} \\
\mathrm{R} / \mathrm{C} & =1,2
\end{aligned}
$$

Dari perhitungan diatas dapat dilihat bahwa $\mathrm{R} / \mathrm{C}$ ratio pada angin musim timur yaitu sebesar 1,5 lebih besar daripada $\mathrm{R} / \mathrm{C}$ ratio pada angin musim barat yaitu sebesar 1,2. Hal ini menunjukkan bahwa $\mathrm{R} / \mathrm{C}$ ratio yang didapat pada usaha pengolahan ikan di Lhok Seudu memberikan keuntungan dan layak untuk dikembangkan. Namun dari $\mathrm{R} / \mathrm{C}$ ratio yang didapat pada angin musim barat menunjukkan bahwa keutungan yag diperoleh akan lebih kecil dari pada angin musim timur yang dapat berpengaruh pada pendapatan pengusaha pengolahan 
ikan sehingga inovasi yang diberikan sangat dibutuhkan untuk menunjang pendapatan pada angin musim barat.

Untuk mengetahui pendapatan sesudah dilakukannya inovasi dengan pengadaan tempat pendingin atau freezer dapat diasumsikan sebagai berikut :

Tabel 5. Asumsi Perbandingan Pendapatan pada Angin Musim Timur dan Angin Musim Barat

\begin{tabular}{|c|c|c|r|}
\hline No. & Uraian & $\begin{array}{c}\text { Angin Musim Timur } \\
(\mathrm{Rp} / \text { Bulan})\end{array}$ & $\begin{array}{c}\text { Angin Musim Barat } \\
(\mathrm{Rp} / \mathrm{Bulan})\end{array}$ \\
\hline 1. & Nilai Produksi & 17.940 .000 & 17.940 .000 \\
\hline 2. & Biaya Produksi & 11.381 .159 & 11.381 .159 \\
\hline \multicolumn{2}{|c|}{$\begin{array}{c}\text { Jumlah Pendapatan } \\
\text { (Rp/Bulan) }\end{array}$} & 6.558 .841 & 6.558 .841 \\
\hline
\end{tabular}

Sumber : Data Primer (diolah), 2016

Dari tabel asumsi diatas dapat disimpulkan bahwa dengan adanya inovasi pengadaan tempat pendingin atau freezer maka pendapatan pada angin musim timur atau pada angin musim barat akan tetap sehingga tidak menimbulkan kerugian pada para pengolah ikan. Selain itu dengan adanya tempat pendingin atau freezer juga dapat menekan biaya produksi sehingga para pengolah ikan dapat menghemat biaya untuk membeli bahan baku pada saat angin musim barat. Dalam perhitungan ini, pehitungan asumsi biaya pengunaan tempat pendingin atau freezer adalah sebesar Rp. 3.000.000 dengan umur ekonomis selama 10 tahun. Asumsi ini menunjukkan dengan adanya inovasi pengadaan tempat pendingin atau freezer sangat berguna untuk meningkatkan pendapatan para pengolah ikan pada musim angin barat. Untuk mengetahui besarnya Revenue Ratio Cost pada inovasi yang diberikan ini maka dapat dihitung sebagai berikut :

$>$ Pada angin musim timur :

$$
\begin{aligned}
& \mathrm{R} / \mathrm{C} \text { ratio }=\frac{\text { Total Penerimaan }}{\text { Total Biaya Produksi }} \\
& \mathrm{R} / \mathrm{C} \text { ratio }=\frac{17.940 .000}{11.381 .159} \\
& \mathrm{R} / \mathrm{C} \text { ratio }=1,5
\end{aligned}
$$

Pada angin musim barat :

$$
\begin{aligned}
& \mathrm{R} / \mathrm{C} \text { ratio }=\frac{\text { Total Penerimaan }}{\text { Total Biaya Produksi }} \\
& \mathrm{R} / \mathrm{C} \text { ratio }=\frac{17.940 .000}{11.381 .159} \\
& \mathrm{R} / \mathrm{C} \text { ratio }=1,5
\end{aligned}
$$

Dari perhitungan diatas dapat dilihat bahwa $\mathrm{R} / \mathrm{C}$ ratio pada angin musim timur dan angin musim barat adalah sama yaitu sebesar 1,5. Hal ini menunjukkan bahwa dengan adanya inovasi pengadaan tempat pendingin atau freezer dapat membantu para pengolah ikan untuk meminimalisirkan kerugian pada saat angin musim barat sehingga pendapatan yang diperoleh akan sama pada saat angin musim timur.

\section{Inovasi Pengadaan Para-Para dari Jaring Marlin}

Para-para adalah wadah balok atau papan yang dilapisi dengan jari kawat. Pada proses pengolahan, para-para yang digunakan terbuat dari jaring kawat yang sifatnya mudah lengket. Apabila ikan yang sudah dijemur diatas para-para kering 
maka para-para tersebut akan diposisikan terbalik dari bentuk semula, lalu parapara tersebut akan dipukul-pukul hingga semua ikan yang melekat pada para-para akan jatuh ke tempat penampungan. Akibatnya jaring kawat pada para-para tersebut akan cepat robek dan rusak. Hal ini akan menambah biaya/pengeluaran para nelayan pengolah ikan per satuan waktu. Pada daerah penelitian para-para yang digunakan adalah para-para jaring kawat, namun ada juga beberapa dari pengolah sudah menggunakan para-para jaring marlin. Apabila diberikan inovasi dapat menggunakan para-para yang terbuat dari jaring marlin. Tujuannya adalah untuk menghemat pengeluaran/biaya yang digunakan untuk membeli para-para dimana harga jaring marlin lebih murah dari pada harga jaring yang terbuat dari kawat.

Perhitungan biaya perbandingan pendapatan para-para jaring marlin dan para para jaring kawat dengan jumlah penggunaan rata-rata para-para sebanyak 26 unit dapat diasumsikan sebagai berikut :

Tabel 6. Asumsi Perbandingan Pendapatan Menggunakan Para-para Jaring Kawat dan Para Jaring Marlin

\begin{tabular}{|c|l|r|r|}
\hline No. & \multicolumn{1}{|c|}{ Uraian } & \multicolumn{1}{c|}{ Jaring Kawat } & \multicolumn{1}{c|}{ Jaring Marlin } \\
\hline 1. & Nilai Produksi & 17.940 .000 & 17.940 .000 \\
\hline 2. & Biaya Produksi & 13.693 .259 & 13.657 .148 \\
\hline \multicolumn{2}{|c|}{ Jumlah Pendapatan (Rp/Bulan) } & 4.246 .741 & 4.282 .852 \\
\hline
\end{tabular}

Sumber : Data Primer (diolah), 2016

Dari tabel asumsi diatas dapat disimpulkan bahwa dengan adanya inovasi pengadaan para-para jaring marlin maka dapat menekan biaya produksi. Penggunaan para-para jaring marlin juga dapat menghemat waktu dan tenaga ketika ikan sudah kering karena akan langsung jatuh ke penampungan tanpa harus dipukul-pukul lagi. Selain itu para-para jaring marlin bersifat anti lengket dan juga mempunyai umur ekonomis jauh lebih lama dibandingkan para-para jaring kawat. Untuk mengetahui besarnya Revenue Ratio Cost pada inovasi yang diberikan ini maka dapat dihitung sebagai berikut :

$>$ Para-para Jaring Kawat

$$
\begin{aligned}
\mathrm{R} / \mathrm{C} & =\frac{\text { Total Penerimaan }}{\text { Total Biaya Produksi }} \\
\mathrm{R} / \mathrm{C} & =\frac{17.940 .000}{13.693 .259} \\
\mathrm{R} / \mathrm{C} & =1,31
\end{aligned}
$$

Para-para jaring marlin:

$$
\begin{aligned}
\mathrm{R} / \mathrm{C} & =\frac{\text { Total Penerimaan }}{\text { Total Biaya Produksi }} \\
\mathrm{R} / \mathrm{C} & =\frac{17.940 .000}{13.657 .148} \\
\mathrm{R} / \mathrm{C} & =1,32
\end{aligned}
$$

Dari perhitungan $\mathrm{R} / \mathrm{C}$ ratio diatas dapat dilihat perbandingan antara parapara jaring kawat dan para-para jaring marlin tidak terlalu besar yaitu 1,31 dan 1,32. Hal ini menunjukkan bahwa $\mathrm{R} / \mathrm{C}$ ratio yang didapat pada usaha pengolahan ikan di Lhok Seudu memberikan keuntungan dan layak untuk dikembangkan. Meskipun dari segi keuntungan menunjukkan persamaan, namun manfaat para- 
para jaring marlin lebih besar dari segi umur ekonomis, penggunaan waktu dan tenaga.

\section{Inovasi Pengadaan Kemasan (Packaging)}

Pada proses pemasaran, ikan hasil olahan dijual dengan cara menjajakannya di kios-kios yang mereka buat di pinggir jalan Banda Aceh - Meulaboh. Ikan-ikan tersebut hanya digantung atau ditumpuk di atas meja sehingga ikan-ikan tersebut akan cepat busuk dan berjamur. Apabila diberikan inovasi dapat dilakukan dengan memberikan pengemasan atau packaging yang bertujuan untuk melindungi makanan agar tidak cepat rusak dan busuk. Pengemasan atau packaging merupakan pengadaan wadah atau pembungkus yang dapat mecegah atau mengurangi kerusakan, melindungi produk dari bahaya pencemaran serta gangguan fisik pada produk. Dengan adanya pengemasan atau packaging juga dapat meningkatkan kualitas produk dan memperindah penampilan produk sehingga dapat menarik minat konsumen.

Berikut merupakan perbandingan pendapatan sebelum adanya inovasi dan sesudah adanya inovasi.

Tabel 7. Asumsi Perbandingan Pendapatan Sebelum dan Sesudah Pengadaan Pengemasan atau Packaging

\begin{tabular}{|c|l|r|}
\hline No. & \multicolumn{1}{|c|}{ Uraian } & Total Pendapatan (Rp/bulan) \\
\hline 1. & Sebelum Inovasi & 4.235 .090 \\
\hline 2. & Sesudah Inovasi & 5.223 .366 \\
\hline
\end{tabular}

Sumber : Data Primer (diolah), 2016

Dari tabel asumsi diatas dapat dilihat bahwa total pendapatan sebelum adanya inovasi pengadaan pengemasan atau packaging adalah sebesar Rp.4.235.090/bulan dan total pendapatan sesudah adanya inovasi pengadaan pengemasan atau packaging adalah sebesar Rp. 5.223.366/bulan. Hal ini menunjukkan bahwa penggunaan pengemasan atau packaging dapat meningkatkan pendapatan para pengolah ikan. Untuk mengetahui besarnya Revenue Ratio Cost pada inovasi yang diberikan ini maka dapat dihitung sebagai berikut :

Tanpa kemasan (sebelum inovasi)

$$
\begin{aligned}
\mathrm{R} / \mathrm{C} & =\frac{\text { Total Penerimaan }}{\text { Total Biaya Produksi }} \\
\mathrm{R} / \mathrm{C} & =\frac{17.940 .000}{13.704 .909} \\
\mathrm{R} / \mathrm{C} & =1,3
\end{aligned}
$$

Pengadaan kemasan (sesudah inovasi) :

$$
\begin{aligned}
\mathrm{R} / \mathrm{C} & =\frac{\text { Total Penerimaan }}{\text { Total Biaya Produksi }} \\
\mathrm{R} / \mathrm{C} & =\frac{19.828 .050}{14.604 .684} \\
\mathrm{R} / \mathrm{C} & =1,4
\end{aligned}
$$

Dari perhitungan $\mathrm{R} / \mathrm{C}$ ratio diatas dapat dilihat perbandingan antara sebelum dan sesudah inovasi dengan perbandingan $\mathrm{R} / \mathrm{C}$ ratio sebesar 1,3 dan 1,4. Hal ini menunjukkan bahwa $\mathrm{R} / \mathrm{C}$ ratio yang didapat pada usaha pengolahan ikan di Lhok Seudu memberikan keuntungan dan layak untuk dikembangkan. Namun dengan 
adanya inovasi dapat meningkatkan keuntungan para pengolah ikan yang ada di Lhok Seudu yang menunjang pendapatan mereka.

\section{KESIMPULAN DAN SARAN}

Tahapan proses pengolahan ikan yang ada di Lhok Seudu Desa Layeun Kecamatan Leupung Kabupaten Aceh Besar dapat dikategorikan sederhana. Usaha pengolahan ikan yang ada di Lhok Seudu Desa memperoleh keuntungandengan $\mathrm{R} / \mathrm{C}$ rasio yang diperoleh adalah sebesar 1,3. Inovasi yang dapat diberikan pada usaha pengolahan ikan yang ada di Lhok Seudu adalah pengadaan tempat pendingin atau frezeer, pengadaan para-para jaring marlin dan pengadaan pengemasan atau packaging.

Untuk meningkatkan pendapatan usaha pengolahan ikan sebaiknya para pengolah ikan meningkatkan kualitas produksi dan melakukan penganekaragaman produk baru sehingga dapat meningkatkan penjualan produksi olahan, memperbaiki sistem pemasaran serta mempeluas pemasaran agar dapat meningkatkan jumlah penjualan sehingga dapat meningkatkan pendapatan dan bagi pemerintah daerah diharapkan dapat memberikan perhatian lebih lanjut terhadap usaha pengolahan ikan baik berupa modal, pembekalan ilmu pengetahuan dan lain-lain sehingga para pengolah ikan mampu meningkatkan kualitas dan kuantitas produksi sesuai permintaan konsumen.

\section{DAFTAR PUSTAKA}

Khairul, F. 2003. Manajemen Proses Pada Pengalengan Ikan Lemuru (Sardinella longiceps) di PT. Pasific Harvest,Banyuwangi, Jawa Timur. (Laporan Praktek Lapang). Akademi Perikanan Sidoharjo.

Kusnadi. 2000. Akuntansi Keuangan Menengah (Intermediate), Prinsip, Prosedur Dan Metode, Edisi Pertama. Brawijaya. Malang.

Mulyadi, S. 2005. Ekonomi Kelautan. PT. Raja Grafindo Persada, Jakarta.

Soekartawi. 1993. Prinsip Dasar Ekonomi Pertanian. PT. Raja Grafindo Persada. Jakarta.

Sukirno, S. 2002. Pengantar Teori Mikroekonomi. PT. Raja Grafindo Persada. Jakarta.

Suparmoko. 2001. Pokok-Pokok Ekonomika. BPFE. Yogyakarta. 2006. Analisis Usahatani. UI Press. Jakarta. 